\title{
Commodity Bundling in Government Securities Auctions: An Analysis of the Primary Dealer Model in Canada *
}

\author{
Samita Sareen \\ Berkeley Research Group \\ New York
}

October, 2011

\begin{abstract}
Does the decision of primary dealers to support government bond auctions depend critically on compensation from the issuer? This paper argues that the answer is yes. Primary dealer system is a widely prevalent method for issuing government securities in which the issuer imposes participation obligations on human intermediaries and compensates them with rents conditional on compliance. A unique data set from the Government of Canada securities auctions is utilized to show that dealers respond strongly to the compensations offered by the issuer when deciding to bid as primary dealers in government bond auctions.
\end{abstract}

Keywords: Bundling, Government Securities, Intermediation, Matching, Primary Dealer

*I thank seminar participants at the Bates White Antitrust Conference 2006, Commodity and Futures Trading Commission, and Moody's Analytics. I have also benefited from discussions with Pat Bajari, Mike Peters and Ali Hortaçsu and gained important institutional insights from several people at the Bank of Canada. The views expressed in this paper are solely those of the author. For correspondence, email:samitasareen@gmail.com 


\section{Executive Summary}

Governments across the world are spending record amounts to reverse what could be the worst recession since the 1930s. This expenditure is financing fiscal stimulus packages, bank bail-outs, surging automatic stabilizers like unemployment compensation, food-stamps, etc. Combined with the mounting funding needs of the government, there is a dramatic decline in the government's tax receipts on account of unemployment, reduced wealth and slowing corporate profits. The result has been unprecedented and large deficits. In the USA, the Congressional Budget Office estimates the 2009 Federal budget deficit to be $\$ 1.2$ trillion, which is more than double the 2008 deficit, and that large deficits are likely to persist for several years into the future.

This makes it vital to understand how sovereign governments fund their budget deficits, and how the method of funding might contribute to the cost of funding.

Government's around the world finance their expenditure by auctioning bonds via the primary dealer model. ${ }^{1}$ As per this issuance model, both intermediaries called primary dealers and investors such as institutions, sovereign funds, hedge funds, etc. can place bids in the auction. But participation obligations are imposed on the primary dealers, and conditional on complying with obligations, compensations referred to as advantages are awarded to them. Dealers who win bonds in the auction can earn a mark-up by either selling them in the liquid post-auction secondary market, or they can finance their winnings in the repo market. In many instances, prior to the auction, dealers enter into forward delivery contracts in a pre-market referred to as the when-issued market, and bid in the auctions to cover their short positions.

A typical participation obligation stipulates that a primary dealer has to bid a minimum amount at each issuance at a price that does not deviate significantly from the when-issued price. Advantages rarely take the form of lump-sum payments made by the government to the dealers conditional on complying with participation obligations. Rather, they are "soft" in nature. Primary dealers are preferred counterparties of the Central Bank in monetary policy implementation and foreign exchange reserve management. Additionally, there are "reputational" benefits in dealing with non-government clients.

The significance of obligations on primary dealers is that it insures the government against an under subscribed or failed issuance, which has serious ramification in terms of level and volatility of funding costs. An immediate consequence of a failed auction is to plug the funding gap of the government by auctioning short-term bills whose costs tend to be volatile. But a more serious repercussion is long-term when sovereign debt downgrades by rating agencies lead to higher debt issuance costs.

\footnotetext{
${ }^{1}$ An IMF (2003) survey of government debt issuance practices across the world reports that $75 \%$ of the surveyed countries use the primary dealer model to issue debt.
} 
But participation obligations on their own cannot guarantee that bidders would agree to participate in the auction as primary dealers as complying with obligations is costly, with costs being manifold in nature ranging from administrative cost to inventory holding costs. What can the government do to incentivize dealers to bid as primary dealers? It can offer them advantages that compensate for the compliance costs.

While the role of mark-ups as incentives to bid as primary dealers is wellrecognized, compensation from the issuer in the form of advantages is little understood. This gap is remedied in this paper. The setting is the market for Government of Canada securities where issuance is conducted by the Bank of Canada via the primary dealer model. The analysis in this paper establishes the link between the decision to bid as primary dealers and the compensation for intermediation awarded by the issuer. It proceeds in two-steps:

- First, it shows that in Canada compensations from the issuer are necessary for a fully subscribed issuance.

- Next, it shows that changes in compensation affects a dealers decision whether or not to bid as a primary dealer.

Several features of data allow this link to be recovered:

- First, through a period spanning 1992-2004, I observe each dealer's decision whether to participate in Government of Canada Securities auctions as a primary dealer or a non-primary dealer.

- Additionally, compensations for intermediation awarded by the issuer to the primary dealers are readily interpretable as the difference between the participation obligations imposed on, and the advantages awarded to the primary dealers by the Bank of Canada.

- Finally, I observe a policy experiment in October 1998 by the Bank of Canada which cut-back on the compensations awarded by the issuer to primary dealers. ${ }^{2}$

A significant vindication of the relative role of obligations vs. advantages that underlie the primary dealer model was the partial reversal of the policy change in December 2005, when following lack-luster primary dealer participation, obligations were made less onerous. ${ }^{3}$

\footnotetext{
${ }^{2}$ As part of this policy changes, dealers were obligated to submit half of the amount they are allowed to bid within 5 basis points of the market-clearing price. Additionally, by preventing primary dealers from cornering more than $25 \%$ of the outstanding supply, their ability to create and profit from a short squeeze was severely curtailed.

3 "The government will reduce Primary Dealers bidding obligations. Under the Terms of Participation for auctions, each PD must bid at every auction for a minimum of 50 per cent of its auction limit at a reasonable price for the government.... The range of bids classified as being at reasonable prices will be increased from the cut-off-yield plus 5 basis points to the cut-off- yield plus 10 basis points for all securities. This easing in requirements will reduce the burden borne by Primary Dealers, thereby supporting auction participation."
}

Changes to the Government of Canada Debt Distribution Framework, p. 4, August 2005 
The credit crisis has drawn attention to the primary dealers in the USA. The unprecedented increase in U.S. Treasury issuance has been accompanied with a demise of primary dealers - Bear Stearns, Lehman, Merrill and Countrywide (both of which were acquired by Bank of America). Consequently, incumbent dealers are obligated to bid for a larger proportion of the issue amount thereby committing larger balance-sheets and associated risks. Currently US Government Treasury auctions are well-subscribed with primary dealers earning significantly larger mark-ups relative to the pre-crisis period. This follows from the surging demand for a safe-haven asset class like U.S. Treasury securities, as well as, the relatively fewer primary dealers. However, as risk appetite returns to the market and the role of the dollar as a reserve currency is questioned, advantages rather than mark-ups are likely to become an important component of the mechanism through which primary dealers are enticed to deliver successful issuances to the US Treasury. 


\section{Introduction}

Existing theory attributes distinct functions to human intermediaries that are difficult for electronic intermediaries to replicate. Grossman (1992) points out that since human intermediaries know the state of nature that will induce a customer to trade, their private information about this unexpressed order flow enables them to match buyers and sellers more efficiently. Seppi (1990) shows that in the presence of information asymmetry, human intermediaries are able to offer better prices to their customers relative to electronic intermediaries, as repeat interactions allow them to identify noise traders and consequently better manage the adverse selection problem. Extensive empirical literature supports the value added by human intermediaries. ${ }^{4}$ In an important and directly related paper, Barclay, Hendershott and Kotz (2005) compare the matching role of voice brokers with electronic brokers in the inter dealer market for U.S. Treasuries. Treasury securities going off-the-run provides them with a natural experiment to establish that voice brokers matching services are most valuable for more difficult trades in less active markets.

Despite the vastly important matching role played by human intermediaries, there is little recognition that providing this "extra" source of value is costly for which they need to be compensated. On the contrary, the higher priced services of human intermediaries have been the subject of extensive debate. Since lower-priced electronic intermediaries increasingly co-exist with human intermediaries in hybrid financial markets around the world, buyers and sellers have low willingness-to-pay for the higher priced human intermediation services. Even less attention is paid to the possibility of market failure of thinly traded financial assets were human intermediaries to completely withdraw their matching services following inadequate compensations. ${ }^{5}$ As a first step to begin unraveling the decision making process of human intermediaries, particularly the economic forces that justify their higher payoffs, establishing the link between a dealer's decision to intermediate and the compensation for intermediation is vital.

This link is examined for the government securities market in this paper. Governments regularly issue securities to finance their expenditure with the issuance typically undertaken by the Central Bank on behalf of the government. The market for government securities is vast in size with the OECD estimating US \$15trillion of outstanding government bonds in 2007.

\footnotetext{
${ }^{4}$ Barclay, Hendershott, and McCormick (2003) compare ECNs with market makers trading in NASDAQ stocks, and show that while the ECNs have a greater market share for the largest and most actively traded stocks, NASDAQ market makers have a larger share in smaller, less liquid stocks with greater information asymmetry. Madhavan and Sofianos (1998) show that NYSE specialists have higher participation rates in smaller, less liquid stocks. While this is not an exhaustive list, this line of empirical research does not disentangle the matching role of human intermediaries from their role in managing the adverse selection problem on account of the information asymmetry.

${ }^{5}$ While this might be considered an extreme scenario, if a large number of human intermediaries were to withdraw their services, the market power and the ease of colluding of the incumbent intermediaries are likely to lead to higher transaction costs for buyers and sellers
} 
In this important market, issuance through human intermediaries called primary dealers is popular despite the inroads made by electronic intermediaries in other markets. The primary dealer system bundles advantages with participation obligations: the issuer imposes participation obligations on dealers in the primary market for government securities, and awards rents in the form of advantages if participation obligations are met. An IMF survey of government debt issuance practices across the world by Arnone and Iden (2003) reports that $75 \%$ of the surveyed countries use the primary dealer model to issue debt. ${ }^{6}$

At first glance the popularity of the primary dealer system might appear puzzling as it is a costly method to issue securities. A large theoretical literature establishes that for a cost minimizing seller more competition is better than less, and the primary dealer model essentially restricts competition. In addition, one might think of the advantages given to intermediaries as essentially transfers from the seller to the intermediaries, and thereby constitute cost for the issuer.

The popularity of the primary dealers and the "extra" compensations awarded to them is directly attributable to the matching role they play in the primary market for government securities by forestalling under subscription of an issuance. A primary market issuance fails or is under subscribed if demand from buyers of government bonds is less than the issue amount. ${ }^{7}$ An immediate effect of persistent fails is government debt downgrades and an increase in issuance costs. By complying with their participation obligations, primary dealers play a critical role in preventing under subscribed issuances. The "extra" compensations awarded by the issuer are a payment for these intermediation services.

In an attempt to reverse what could be the worst recession since the 1930s, many countries are issuing record amounts of government bonds to pay for fiscal stimulus packages and bank bail-outs. This has been accompanied by a reduction in the number of primary dealers on account of collapse of banks, as an example Bear Stearns and Lehman, and merger of others like Bank of America and Merrill. Yet, there are no systematic instances of dealers failing to absorb the supply of government bonds in countries that issue bonds via the primary dealer model (as an example, USA and UK). The sovereign bond that has been persistently shunned by investors during the credit crisis belongs to Germany, a country that does not issue debt through primary dealers:

"A German sovereign bond auction failed on Wednesday as investors shunned one of the most liquid and safe assets in the world in a warning for governments

\footnotetext{
${ }^{6}$ The remaining $25 \%$ issue securities through an open participation system in which participation is unrestricted: the issuer neither imposes obligations nor awards advantages in return. Amongst the developed countries, Canada, UK, Italy, Spain and Sweden issue government securities through intermediaries, while in USA, Germany, and Austria participation is open. Amongst the developing countries, India, Mexico, Ghana, Morocco, Thailand used the primary dealer model, and Kenya, Latvia and Indonesia used the open participation model.

${ }^{7}$ Essentially this implies that the primary market clears at a price that is significantly below the market price. In treasury markets, the market price is the price in the forward market, referred to as when-issued market. Since the forward market overlaps with the primary market, the when-issued price plays the role of a marginal cost of issuance in the primary market.
} 
seeking to raise record amounts of debt to stimulate slowing economies. The fate of the first eurozone bond auction of 2009 signals trouble ahead as governments around the world hope to issue an estimated $\$ 3000 \mathrm{bn}$ in debt this year, three times more than in 2008. The 10-year bonds failed to attract enough bids to reach the $6 \mathrm{bn}$ the German government wanted. Bids of Eur5.24bn, a cover of only 87 per cent, amounted to the second worst auction on record in terms of demand. Such developments were rare before the credit crisis. Before the seven German bond auctions that failed last year, the last German bond auction to fail was in July 2000 after the dotcom crash.

(David Oakley, German bond sale's fate signals trouble ahead, January 72009 , Financial Times.)

The Japanese experience during 2002-2004 is particularly relevant. Following persistent auction failures of the benchmark 10-year Japanese Government bonds, the government actually switched to the primary dealer model in 2004:

"those who trade in and oversee the market, harbor painful memories of an under-subscribed JGB auction in 2002, the first in more than a decade. The failure sent bond yields soaring and shocked the finance ministry, which manages Y483,000bn of outstanding JGBs - the largest government bond market in the world - and knows it has to sell more debt to the market every year. "We now have a safety net for the auctions," says Susumu Kato, chief JGB strategist at Lehman Brothers, one of the primary dealers. "Investors and dealers used to see auctions as an event-risk, but that is no longer the case." Judging from the results of recent monthly auctions, the primary dealer system has made the prospect of another failed sale very distant. At the past July and August auctions were 3 times and just under 9 times covered....

(Barney Thomas, No Thrills System Tames JGBs, December 1 2004, Financial Times.)

The setting in this paper is the market for Government of Canada securities where primary issuance has been conducted by the Bank of Canada via the primary dealer model. My analysis establishes the link between the decision to intermediate by the primary dealers and the compensation for intermediation awarded by the issuer. It proceeds in two-steps:

1. First, I show that in Canada compensations for intermediation from the issuer are necessary for a fully subscribed issuance.

2. Next, I show that changes in compensation for intermediation affects a dealers decision whether or not to provide intermediation services.

Several features of my data and the specific setting of the Government of Canada Securities market allow me recover the link. Through a period spanning 1992-2004, I observe each dealer's decision whether to participate in the primary issuance process as a primary dealer or a non-primary dealer. Additionally, compensations for intermediation awarded by the issuer to the primary dealers 
are readily interpretable as the difference between the participation obligations imposed on, and the advantages awarded to the primary dealers by the Bank of Canada. Finally, I observe a policy experiment in October 1998 by the Bank of Canada which cut-back on the compensations awarded by the issuer to primary dealers.

To begin with, Section 2 describes the setting in the primary market for government securities that leads to under subscribed issuances. Section 2.1 provides a detailed overview of the data set and the institution of primary dealership in Canada. Section 2.3 describes the policy experiment by the Bank of Canada in October 1998 which reduced the compensation of primary dealers. By increasing the cost of complying with participation obligations and cuttingback on the rents embodied in advantages, the issuer de facto offered primary dealership at a higher price.

Next, Section 3 establishes that there is a high likelihood of failed issuances if the issuer does not compensate the dealers for intermediation services. For this one of the unique aspects of this data set is utilized: the change in a dealer's decision whether to participate as a primary dealer or a non-primary dealer over the entire sample period. Putting this piece together with the increase in the price of primary dealership embodied in the 1998 policy experiment, reveals that only seven dealers are likely to participate as primary dealers without being compensated by the issuer for intermediation services. Counterfactual primary issuances with these seven primary dealers are under subscribed, ceteris paribus. This section also suggests that the participation decision of the seven primary dealers might be attributable to their access to dedicated investors with whom allotted securities can be traded. ${ }^{8}$ This access implies that in addition to the compensations from the issuer through the primary dealer contract, these dealers also receive payments for intermediation through their dedicated investor networks. ${ }^{9}$ Their decision to participate despite a cutback in rewards from the seller suggests that payments from these buyers are significant. ${ }^{10}$

Finally, logit regressions in Section 4 show that for dealers other than the seven high reserve value dealers, the decision whether or not to participate as a primary dealers is highly sensitive to the compensation offered by the issuer after controlling for compensations from the customer investors.

This paper contributes to market microstructure literature an extensive survey of which is available in Biais, Glosten and Spatt (2004), O'Hara (1997), and Lyons (2001). Theoretical microstructure literature has attributed three roles to

\footnotetext{
${ }^{8}$ Anecdotal evidence suggests that dealers typically incur substantial fixed costs to develop these investor networks.

${ }^{9}$ Compensations from buyers takes the form of a markup: the difference between the price at which securities are issued in the primary market and the price at which they are either pre-sold in the when-issued market or sold ex post in the secondary market.

${ }^{10}$ Depending on their market power, dealers with investor-networks can simply pass through some or all of the price increase in primary dealership associated with a decline in compensations from the issuer.
} 
intermediaries: price setting, providing immediacy and liquidity, and coordinating buyers and sellers. The payoff for providing these services takes the form of a bid-ask spread. Empirical microstructure research establishes what explains bid-ask spread: as an example, order-handling costs, inventory costs, adverse selection, and monopoly power. A question largely unexplored is the decision of an intermediary whether or not to provide intermediation services, and the extent to which it depends on payments for intermediation. This is remedied for the vast government securities market in this paper. In this market the role of intermediaries is indisputable: by complying with participation obligations, primary dealers guarantee a fully subscribed issuance. This paper is perhaps the first of its kind to directly link a dealer's decision to provide intermediation services to the issuer with the payoff received, with the payoff here taking the form of advantages net of obligations.

This paper also complements theoretical and empirical analysis of treasury markets. Several theoretical papers compare the expected cost to the seller of issuing treasury securities under the discriminatory and uniform price rule for multi-unit first-price, sealed-bid auctions. ${ }^{11}$ There is also extensive empirical work that has focussed on revenue comparisons of uniform vs discriminatory pricing rules in treasury auctions. ${ }^{12}$ But the wide prevalence of the primary dealer system suggests that provision of intermediation services involves participation costs, with the results in this paper suggesting that these are sufficiently binding for dealers to prevent them from bidding unless they are compensated by the issuer. Indeed, the first-order importance of participation costs for primary dealers is likely to make revenue comparisons of auction formats highly sensitive to the compensations paid out by the issuer for the same.

\section{Primary Dealership System for Government Securities}

In most countries, the process of issuing government securities links three markets: the when-issued, primary and secondary markets. The process begins with the Central Bank, ${ }^{13}$ referred to henceforth as seller or issuer, soliciting bids in the primary market with a bid submission deadline typically two weeks later. Selling mechanisms range from an auction to a take-it-or-leave-it offer in the from of a syndicate. The when-issued market begins almost immediately following the solicitation of bids in the primary market. In this market dealers

\footnotetext{
${ }^{11}$ As an example, Ausubel and Cramton (1997), Engelbrecht-Wiggans and Kahn (1998), Bikhchandani and Huang (1989), Back and Zender (1993), and Noussair (1993). Surveys by Chari and Weber (1992), Bikhchandani and Huang (1993), Das and Sunderam (1997) and Malvey and Archibald (1998) provide an excellent summary.

${ }^{12}$ Umlauf (1993), Simon (1994), Nyborg and Sundaresan (1996), Malvey and Archibald (1998), Goldreich (2004), Hortaçsu (2002), Kastl (2006).

${ }^{13}$ In countries (for example, the USA and UK) where there is a separation of the fiscal agent and the monetary policy agent of the Central Bank, primary issuance is conducted by the Debt Management Office
} 
engage in forward trading of the security that is yet-to-be-issued in the primary market. Following issuance in the primary market, the securities are actively traded in the secondary market. Figure 1 presents the time-line of the issuance process. The overlap between the when-issued market and the primary issuance process up till the point at which the seller announces the market clearing price, makes government securities fairly commoditized.

The subject of this paper precedes the bid solicitation process. Prior to announcing the issuance or how it will be run, the issuer has to decide from whom he will solicit bids. He has the choice of inviting only intermediaries who will then sell the securities to final investors. Alternatively, participation could be open in that any investor can bid in the primary issuance. In the setting in this paper the issuer invites intermediaries to participate in the issuance process, and the focus is on the decision of the dealers whether or not to provide intermediation services.

The intermediation process in the market for government securities works as follows. The Central bank invites intermediaries called dealers to participate in the issuance process. Dealers can chose whether they wish to participate as primary dealers or other dealers. Dealers who bid as primary dealers have to comply with participation obligations imposed by the seller. ${ }^{14}$ A typical obligation stipulates that a dealer has to bid a minimum amount at each issuance at a price that does not differ significantly from the when-issued price. ${ }^{15}$ Participation obligations are like entry costs for dealers: dealers know ex ante that they have to bid in the primary market in a manner that is consistent with their obligations, ex post. ${ }^{16}$ The nature of entry costs is manifold ranging from administrative cost of complying with obligations to inventory holding costs. ${ }^{17}$

\footnotetext{
${ }^{14}$ The exact form of these obligations varies across countries as described in Sareen (2004). Section 2.3 details these as they apply in Canada.

${ }^{15}$ In Treasury markets, the when-issued price can be interpreted as the marginal cost of the issuer. This follows from the significant overlap between trading in the when-issued market and primary market issuance process; additionally, the security could be trading in the market prior to the auction if the current issuance is a reopening of a previously issued security.

${ }^{16}$ A primary dealer's profits will eventually be determined by the demand he faces in the when-issued and secondary markets. However, he does know that irrespective of this demand, he will be obligated to win a certain fraction of the issue amount at a price that equals marginal cost: the when-issued price prevailing prior to the bid submission deadline. Thus, the entry cost is similar in nature to that mentioned by Samuelson (1985) in the literature on endogenous entry of bidders in auctions. The entry process will distort a dealer's private value distribution since the probability of participating as a primary dealer will depend on whether his valuation exceeds the costs of meeting the obligations. This is quite different from endogenous entry models in McAfee and McMillan (1987) and Levin and Smith (1994) where bidder's first incur entry costs and then observe their valuations making entry independent of a bidder's valuation.

${ }^{17}$ Microstructure models cite this as one of the costs of intermediation for a market maker (Demsetz, 1968; Stoll, 1978; Ho and Stoll, 1981). To provide immediacy, a market maker holds an inventory of securities, which could be costly if the market moves against him. Inventory models of microstructure attribute the bid-ask spread as a compensation of the market maker for bearing the cost of this price risk. A dealer who is obligated to bid seriously is likely to win as well; he will incur inventory holding costs on the securities neither (pre-)sold in the when-issued markets nor secondary markets.
} 
Conditional on complying with participation obligations, the seller awards advantages to dealers. ${ }^{18}$. Following from a Central Bank's interaction with dealers in markets other than the government securities markets during the process of monetary policy implementation and foreign exchange reserves management, advantages are awarded in multiple markets. Sareen (2004) documents these advantages for several countries.

The seller's choice of the primary dealer model and the consequent matching role played by the dealers hinges critically on the likelihood of under subscription. ${ }^{19}$ An issuance is under subscribed if demand is less than the issue amount, with the primary market clearing only at a price that is significantly below the when-issued price. To clarify the seller's problem I shall refer to participation in the primary market that is subject to minimum bid amount and yield obligations as frequent participation, and treat it like a commodity sold by the issuer at a price $P_{\text {freq }}^{*}$. Suppose Figures 2(a) and 2(b) are two possible distributions of buyers in the reserve value space for frequent participation. A dealer's reservation value for frequent participation is plotted on the $\mathrm{X}$-axis. Each dealer is uniquely mapped to a reservation value and represented by a cross. To begin with the Y-axis is left undefined, so that Figure 2(a) and 2(b) are one-dimensional plots, and the vertical line represents the selling price $P_{\text {freq. }}^{*}$ A dealer is likely to purchase frequent participation, or subject himself to participation obligations, only if his reservation value for frequent participation is at least as high as the selling price of the issuer. In Figures $2(\mathrm{a})$ and $2(\mathrm{~b})$, these high reservation value dealers are located on the right of the price line $P_{f r e q}^{*}$. Dealers located on the left of the price line have a reservation value lower than $P_{\text {freq }}^{*}$ suggesting that participation obligations are likely to be binding on them, and consequently they are unlikely to purchase frequent participation.

Under subscription of an issuance is unlikely to be a problem for the seller were he to encounter the distribution of buyers corresponding to Figure 2(a). This follows from the presence of large number of high reservation value dealers making seller compensation for intermediation redundant in this scenario. ${ }^{20}$ But the situation in Figure 2(b) is quite different: there are many buyers with low reserve value for frequent participation but only few with high reserve value for frequent participation. A failed issuance is now a distinct possibility. The primary dealer model offers one channel through which the seller can forestall under subscription: by offering to compensate dealers for complying with obligations, he can lower the price of frequent participation relative to dealers' reserve value, to the point where the low reservation value dealers (those located on the left of $P_{\text {freq }}^{*}$ in Figure 2(b)) are enticed to purchase frequent participation. Again for clarity of exposition, compensations are treated like a commodity

\footnotetext{
${ }^{18}$ There have been numerous instances of advantages being withdrawn when primary dealers fail to comply with obligations.

${ }^{19}$ The phenomenon of under subscription is also referred to as uncovered or failed issuance.

${ }^{20}$ USA is a representative example of a country where the distribution of buyers in the reservation value space for frequent participation would resemble Figure 2(a). This follows from the US dollar being the reserve currency of the world. Not only banks and financial institutions, but Central Banks across the world bid in the US Treasury auctions.
} 
advantages. The primary dealer model compensates dealers with advantages conditional on dealers subjecting themselves to minimum bid amount and yield obligations; in short, it bundles advantages with frequent participation. Additionally, since participation requirements essentially obligate primary dealers to provide "matching" services by stepping in between the seller and the final investors of government securities, advantages are in effect compensations for intermediation.

Figure 2(c) illustrates the primary dealer model. As in Figure 2(a) and 2(b), a dealer's reservation value for frequent participation is plotted on the $\mathrm{X}$-axis. A dealer's reserve value for advantages is plotted on the Y-axis. The price at which the issuer "sells" primary dealership is $P_{B}^{*}$. The slope of the primary dealer price line $P_{B}^{*} P_{B}^{*}$ is the ratio of the price of frequent participation to the price of advantages. Since advantages awarded to buyers are similar to rents the price of advantages can be treated like a numraire. The price of primary dealership is then the price of frequent participation normalized for rents in the form of advantages. It is obvious from a comparison of the slope of $P_{\text {freq }}^{*} P_{\text {freq }}^{*}$ with that of $P_{B}^{*} P_{B}^{*}$, that by giving advantages in the primary dealer model, the issuer reduces the selling price of frequent participation. As participation obligations become costlier, the price of frequent participation, and consequently the price of primary dealership increases. Similarly, as the rents embodied in advantages decrease, the price of primary dealership increases.

Once the primary dealer contract is offered, potential buyers whose reserve value exceed the price of primary dealership choose to participate as primary dealers. These potential buyers are located in the reserve value space above $P_{B}^{*} P_{B}^{*}$. With the primary dealer contract, the seller entices buyers on the left of $P_{\text {freq }}^{*}$ to participate as primary dealers. These buyers chose not to purchase frequent participation when the issuer sold it without bundling it with advantages, but choose to participate as primary dealers when the issuer bundles it with advantages under the primary dealer system. ${ }^{21}$ The relative decline in the price of frequent participation under the primary dealer model entices these buyers to purchase frequent participation.

\subsection{Description of Data and Surrounding Primary Dealer Institution in Canada}

The Bank of Canada, on behalf of the Government of Canada, issues bonds and treasury bills. ${ }^{22}$ The average issue size for bonds and treasury bills is 5.5 and 2.4 billion Canadian dollars, respectively. Like most countries, the Canadian

\footnotetext{
${ }^{21} \mathrm{By}$ offering the primary dealer contract, the issuer will lose buyers who are located to the right of $P_{\text {freq }}^{*}$ and below $P_{B}^{*} P_{B}^{*}$. These are buyers who have a high reserve value for frequent participation but low reserve value for advantages. Given that advantages are defined as rents accruing to the buyers, it is unlikely that there would be any buyers in this part of the reserve value space.

${ }^{22}$ Bonds have a maturity of $30,10,5$ and 2 years, and treasury bills are zero-coupon bonds with a maturity of 1 year, 3 months and 6 months.
} 
debt issuance process involves the three markets described above: when-issued, primary and secondary markets. In terms of the time-line in Figure 1, the whenissued market commences almost immediately following the announcement of an issuance two weeks prior to the bid submission deadline.

During the period of this study, 1992-2003, the primary dealer system was used for issuing Government of Canada debt. Primary issuance was organized as a discriminatory price auction in which both primary dealers and non-primary dealers could participate. ${ }^{23}$ On an average, 12.7 primary dealers and 13.5 nonprimary dealers participate in an auction. Of the two groups, primary dealers play a central role in both the primary and secondary markets for government securities. The average annual market share of primary dealers was $80 \%$ in the primary market and over $90 \%$ in the secondary market. ${ }^{24}$

I now present evidence that the Bank of Canada has indeed been successful in covering it's auctions at competitive prices by distributing debt through the primary dealer system.

Even though the average number of primary dealers and non-primary dealers in an auction is comparable, the variance of the number of non-primary dealers is almost ten times that of primary dealers. This suggests that participation obligations have in some sense guaranteed an average of 12 primary dealers in most of the auctions in the sample, and participation obligations are spread between these dealers.

Perhaps what is more important is that between them, the 12 dealers that are on an average present in an auction, actually purchased the amount offered by the issuer at competitive prices. To support this, I examine the ratio of the total bid amount to the issue amount in an auction, referred to as the coverage or cover ratio of an auction. An auction in which demand (bid amount) is greater than supply (issue amount) will have a coverage greater than 1 indicating that the seller is able to sell securities corresponding to the issue amount. On an average, for every dollar issued in an auction, the total bid amount is $\$ 2.18$ and $\$ 2.29$ for treasury bills and bonds, respectively. But is this issuance done

\footnotetext{
${ }^{23} \mathrm{~A}$ further distinction can be made between the non-primary dealers: other government securities distributors and customers. The Bank of Canada designates certain institutions as distributors of government securities. These institutions are obligated to buy and sell securities to individual investors. Some of the government securities distributors are primary dealers: they are subject to participation obligations and given advantages in return. Government securities distributors other than primary dealers are neither subject to obligations nor awarded advantages. While government securities distributors - both the primary dealers and others - can bid directly in the auctions, customers cannot do so. They have to bid either through primary dealers or other government securities distributors. Customers comprise of institutional investors like pension funds, hedge funds and mutual funds. Other government securities distributors are typically dealers who service small customers, and this is reflected both in their relatively insignificant primary market and secondary market share which are on an average under $1 \%$ and $2 \%$, respectively. Of the 13.5 non-primary dealers that participate in an average auction, there are 4.9 other government securities distributors and 8.6 customers.

${ }^{24}$ The primary market share is the share of the primary dealers in auction winnings. The secondary market share refers to the share of primary dealers in the weekly volume traded reported by all dealers.
} 
at marginal cost, which in the current context is the when-issued price? For this, I examine the ratio of the cumulative bid amount at cutoff yield plus 5 basis points to the issue amount in an auction, the cutoff yield being the yield at which demand is at least as large as supply. ${ }^{25}$ I find that over $80 \%$ of the bid amount is bid at a yield that is less than or equal to the cutoff yield plus 5 basis point: for every dollar of the issue amount, the Bank of Canada receives bids in excess of $\$ 1.6$ at competitive prices. Next, I test the difference between the when-issued yield just before the bid submission deadline in the primary market and the price that clears the primary market. I find this difference to be insignificant. ${ }^{26}$ Thus, in an average auction not only are the aggregated bids much larger than the issue amount, but these bids also come in at yields that are competitive.

Finally, I do not notice systematic instances of failed issuance in the time period covered by this study.

My data captures several aspects of the primary dealer model in Canada from both the perspective of the issuer and the primary dealers.

With regard to the primary dealers, a significant aspect of the data is that for each auction conducted by the Bank of Canada during the sample period, I am able to observe whether a bidder participated as a primary dealer or a nonprimary dealer. More importantly, I am also able to track a bidder who was present in at least one auction in the sample through the sample period. This allows me to observe changes in each individual bidder's participation choice through the course of my sample.

For each bidder, I also observe his bid schedule in each auction that he participates which allows me to obtain his primary market share in each auction. Each dealer submits bi-weekly reports of total volume traded in the secondary and the repo markets to the Bank of Canada through the Investment Dealers Association of Canada. I observe this data as well, and from this I can infer the bi-weekly secondary market trading share of a dealer, as well as, this dealer's repo trading to his secondary market trading. In Sections 3 and 4 these variables serve as a proxy for compensation received by dealers from clients as dealerspecific order book data is not available.

From the perspective of the issuer, the single most important data observed is the manner in which advantages and obligations underlying the primary dealer contract changed over time. But since this data is not quantitative, but rather qualitative, these changes are described with reference to the policy experiment

\footnotetext{
${ }^{25}$ Bids that come within 5 basis basis points of the cutoff are considered to be competitively priced by traders in this market.

${ }^{26}$ The Bank of Canada records the when-issued yield one hour prior to the auction deadline unless there is a change in the one-hour period before the auction deadline. I tested whether the difference between this when-issued yield and the cutoff yield is significantly different from zero. I find that there is a difference of 2 and 1 basis points for treasury bills and bonds respectively; the test statistic is 11.3 for treasury bill auctions, and 2.8 for bond auctions.
} 
by the Bank of Canada in October 1998 which modified the existing debt distribution framework in a manner that negatively affected dealers' incentives to bid as primary dealers. ${ }^{27}$

\subsection{The October 1998 Policy Experiment}

The risk of a failed issuance that formed the background for the changes made to the debt distribution framework are succinctly summarized in Figures 3 and 4. Figure 3 plots the ratio of bid amount to issue amount at the cutoff yield plus 5 basis points, averaged across auctions in a year, for the three month Tbill and thirty year bond. These two securities had the lowest coverage ratio, amongst treasury bills and bonds respectively, during the period covered by the sample. While T-bill auction coverage declines marginally in 1997, the decline in auction coverage for the 30 year bond is indeed dramatic, falling just below 1 in the period preceding the policy experiment. Figure 4 is a plot of the number of primary dealers. It mirrors the coverage graphs in that the decline in coverage in Figure 3 appears to be a direct consequence of the significantly smaller number of primary dealers in bonds than in T-bills.

The single-most important change made in October 1998 was the imposition of formal minimum bid amount and yield obligations. ${ }^{28}$ Prior to this policy experiment, participation obligations were informal and to that extent nonbinding since primary dealers were not punished (for example, by a withdrawal of their advantages) for failing to comply with these obligations. This left the seller exposed to the risk of under subscribed auctions:

"Prior to the modifications to the framework, there were no formal obligations for large market participants to participate at each auction and the government faced the risk of holding an uncovered auction in which it could not sell all of the securities it offered to meet its financial obligations. Another risk faced by the government was that bids at auctions could significantly differ from the fair market price of securities."

Review of the Government of Canada Debt Distribution Framework, October 2004.

A second component of the policy experiment was directly targeted at a

\footnotetext{
${ }^{27}$ This particular experiment with the debt distribution framework, as well as, the ones in the past and future, can be construed as attempts by the seller to find the minimum compensation that will induce dealers to participate as primary dealers. For example, prior to the sample covered by this study, the Bank of Canada issued government securities via syndication instead of auctions. This was abandoned in favor of auctions as it was felt that the Bank of Canada was paying very large compensations to primary dealers in the form of syndication fee, and that switching to auctions would reduce their magnitude.

${ }^{28}$ There were two parts to this. First, $50 \%$ of the maximum amount that a dealer could bid had to be bid at market clearing price plus 5 basis points. But a profit maximizing dealer could strategically respond by refusing to bid as a primary dealer leaving the seller exposed to auction coverage and price risks. Hence a second part was put in place: dealers whose primary and secondary market shares exceed a threshold were obligated to bid as primary dealers and comply with the participation obligations.
} 
primary dealer's potential to create and profit from a squeeze. ${ }^{29}$ Extensive evidence of persistent "squeezes" for Government of Canada securities has been documented through the 1990s. ${ }^{30}$ This was the result of a bidder's pre-auction holdings of a security not being netted prior to determining the maximum amount he could win. Consequently, a dealer could corner more than $25 \%$ of the stock of a security despite not being allowed to win more than $25 \%$ of the auction. ${ }^{31}$ Primary dealers potential to build-up large pre-auction holdings, and their preferred access to the primary market aided them in creating and profitably free-riding on a created squeeze. ${ }^{32}$ That this indirectly constituted an advantage for the dealer is revealed by the magnitude of rents made by primary dealers following a squeeze:

"The $4 \%$ bond due 15 March 15 traded as much as 50 basis points below the yield on bonds with a similar maturity, and repo rates occasionally fell well below $1 \%$ (general repo rates were about 3.25\%)."

Proposed revisions to the rules pertaining to auctions of Government of Canada securities and the Bank of Canada's surveillance of the auction process, 8 April 1998.

The potential to create a squeeze was curtailed drastically following the October 1998 policy experiment. ${ }^{33}$ Not only were bidders obligated to report their net positions of the auctioned security, but these positions were netted out prior to determining a bidder's eligibility.

Several reasons suggest that the policy experiment raised the price of primary dealership (which in terms of Figure 2(C) translates into a steeper price line

\footnotetext{
${ }^{29}$ A "squeeze" occurs when market participants enter into contracts to deliver a security at some future date, but are then unable to purchase or borrow that security for delivery on the specified date at a price close to that anticipated in the contracts because one or a group of market participants, has cornered the stock of the security. It is often very costly for those caught in the squeeze to meet their contractual obligation to deliver the security.

${ }^{30} \mathrm{See}$ "Proposed revisions to the rules pertaining to auctions of Government of Canada securities and the Bank of Canada's surveillance of the auction process", 16 December 1996 and 8 April 1998; these are available at www.bankofcanada.ca. There were a number of indicators of a possible squeeze in the market. These include special repo rates, how far specific issues trade off the theoretical yield curve, declines in market volume, and increases in concentration of specific issues. Any of these situations can occur under normal market conditions and of themselves are not an indicator of a squeeze. However in the Canadian market through the 1990s, price distortions are large and persistent, and liquidity in the relevant securities in the cash and repo markets was seriously impaired, with the Bank of Canada frequently injecting a supply of the squeezed security through auctions outside the regular cycle.

${ }^{31}$ These position are generally acquired by dealers in the when-issued market. Alternatively, in the case of an auction that is a re-opening of a previously issued security, the positions may have been acquired from the previous issuance.

${ }^{32}$ Nyborg and Strebulaev (2004) analyzing a strategic model of short squeezes in discriminatory auctions actually show that creating and profiting from a squeeze is the best response of a dealer with a long position.

${ }^{3}$ There is extensive evidence that the rule change was effective in stemming the persistent squeezes of the 1990s. See "Review of the Government of Canada Debt Distribution Framework", October 2004.
} 
$\left.P_{B}^{*} P_{B}^{*}\right)$. In the period succeeding the policy change, the number of primary dealers in bonds declined by $33 \%$ from a high of 13 to a low of 10. For T-bill auctions was less dramatic with a much lower decline of $10 \%$, but as Figure 4 indicates the coverage problem was also less severe prior to the policy change. Perhaps the most significant indication that bidding became costly for primary dealers is a subsequent change in December 2005 in which the Bank of Canada reversed a part of its policy experiment by making participation obligations less onerous following persistent exits of primary dealers; ${ }^{34}$

"The government will reduce Primary Dealers bidding obligations. Under the Terms of Participation for auctions, each PD must bid at every auction for a minimum of 50 per cent of its auction limit at a reasonable price for the government.... The range of bids classified as being at reasonable prices will be increased from the cut-off yield plus 5 basis points to the cut-off yield plus 10 basis points for all securities. This easing in requirements will reduce the burden borne by Primary Dealers, thereby supporting auction participation."

Changes to the Government of Canada Debt Distribution Framework, p. 4, August 2005

\section{Issuer Compensations for Intermediation are Necessary in Canada}

Would the Bank of Canada issuances be fully subscribed were it not to compensate primary dealers for complying with participation obligations? This section suggests that the answer is "no".

The analysis rests on combining the policy experiment with dealers decision whether or not to participate as a primary dealer. To being with, it allows me to identify dealers whose participation decision is relatively unaffected by whether or not they are compensated by the issuer for their matching services in complying with participation obligations. These dealers clearly have a high reservation value for frequent participation. Next, I show that counterfactual auctions in which only these dealers are present, are under subscribed. Finally, I bolster the hypothesis that the seven dealers who consistently bid as primary dealers have a high reservation value by examining whether compensations from dedicated investor networks might be it's source.

\subsection{Dealers with High Reservation Value for Frequent Par- ticipation}

Identifying dealers in the sample with high reservation value for frequent participation from data on dealers' participation choice is relatively straightforward if two distinct regimes are observed in the sample. In the first regime as in

\footnotetext{
${ }^{34}$ This paper covers the time period 1992-2003; data beyond this time period has not been made available.
} 
Figures 2(a) and 2(b), the issuer imposes participation obligations but does not offer advantages conditional on complying with them. ${ }^{35}$ In the second regime as in Figure 2(c), primary dealership is offered whereby advantages are offered conditional on complying with participation obligations. Dealers who chose to participate as primary dealers, but who also chose to comply with participation obligations without advantages, are likely to have a higher reservation value. Dealers who chose to participate as primary dealers, but who also chose not to comply with participation obligations without advantages, are likely to have a lower reservation value. ${ }^{36}$

But I do not observe two distinct regimes. Rather, through the sample in Canada, the primary dealer model has been used to issue Government of Canada securities. However, the policy experiment described in Section 2 is tantamount to an increase in the price of primary dealership: following the policy experiment, the price line $P_{B}^{*} P_{B}^{*}$ is steeper in Figure $2(\mathrm{c})$. Since $P_{\text {freq }}^{*} P_{\text {freq }}^{*}$, the price line under the unbundling regime is simply the limiting case of the price line $P_{B}^{*} P_{B}^{*}$ as advantages approach zero, the steeper slope of the latter consequent to the policy change, allows me to observe an unbundling regime, albeit in it's non-limiting version. Combining this price increase with dealers response in terms of electing whether to participate as primary dealers or non-primary dealers, allows me to isolate primary dealers who have a high reservation value for frequent participation by exploiting the revealed preference approach in a fairly straightforward manner. ${ }^{37}$ Thus, dealers who participate in almost all auctions in the sample have a high reservation value for frequent participation. I find that five and seven dealers bid as primary dealers in almost treasury bill and bond auctions, respectively. ${ }^{38}$

\subsection{Counterfactual Auctions are Under Subscribed}

In this section two counterfactual auctions are constructed in which only the high reserve value dealers participate. Both counterfactual auctions suggest that

\footnotetext{
${ }^{35}$ In the parlance of Adams and Yellen (1976), this is akin to an unbundling regime whereby the seller offers frequent participation exclusively.

${ }^{36}$ This follows from the lower price of frequent participation in the primary dealer regime on account of advantages that are a part of the latter but not former.

${ }^{3}$ This is the weak axiom of revealed preference; See Varian (1990, pp. 120-126), and MasCollel, Whinston, Green (1995, pp. 28-31). The basic idea underlying the axiom is that for a maximizing agent, if $x$ and $y$ are two consumption bundles both of which are in his budget set, then if he chooses $x$ over $y$, he must prefer $x$ over $y$ or rank $x$ over $y$ in utility or profit terms. An agent's observed behavior is consistent with maximizing behavior if for two possible distinct prices $p$ and $q$ at which $x$ and $y$ can be purchased, as long as $x$ and $y$ are in his budget set, he chooses $x$ over $y$ irrespective of the price. The revealed preference setup translates into the current context if $x$ and $y$ indicate primary dealership and non-primary dealership, respectively, each being a distinct "bundle" of frequent participation and advantages: primary dealers are subject to minimum bid amount and yield obligations but non-primary dealers are not; primary dealers are awarded advantages while non-primary dealers are not. The two price points $p$ and $q$ are the price of primary dealership, i.e. the relative price of frequent participation viz-a-viz advantages, before and after the policy experiment.

${ }^{38}$ Other dealers bid as primary dealers between $20-60 \%$ of the auctions in the sample, and the participation proportion of the two groups is statistically different.
} 
were the issuer not to compensate dealers for intermediation so that only the seven high reserve value dealers are present in an issuance, there may indeed be a problem issuing debt at marginal cost, making the primary government debt market scenario in Canada closer to Figure 2(b) rather than Figure 2(a).

In the first counterfactual each of the seven dealers bids only at the margin of a primary dealer's obligation, but no more. Currently, the highest amount a primary dealer could be obligated to bid in Canada is $12.5 \%$ of the issue amount in an auction. ${ }^{39}$ To get primary dealers to submit serious bids, current terms of participation for primary dealers also require that this amount is bid at prices that are within 5 basis points of the cutoff yield. The first counterfactual assumes that each of the seven dealers bids $12.5 \%$ of the issue amount within 5 basis points of the cutoff yield in each auction. This is the worst-case scenario for the seller as each dealer bids only what he is obligated to bid, but no more. In this counterfactual auction, serious bidding would account for only $85 \%$ of the issue amount. The seller would be unable to issue securities corresponding to the issue amount within 5 basis points of the market clearing price, suggesting that covering the auction is indeed a problem in this worst-case scenario.

The second counterfactual is the best-case scenario for the seller: each of the seven dealers bids the highest amount (as a proportion of the issue amount) ever won by a dealer in the sample. As expected, the auction coverage improves dramatically in this counterfactual compared with the worst-case scenario. The highest amount that a dealer has won in an auction the sample is $20 \%$ of the issue amount in the auction. With each of the seven dealers bidding at this level, the cover ratio in the best-case counterfactual auction is 1.4. But this is significantly lower than the average cover ratio actually observed in the sample: for every dollar issued, the seller receives $\$ 2$ worth of bids within 5 basis points of the cutoff yield in the auction. Clearly, with only seven dealers the seller is unable to match the auction coverage in the best-case counterfactual auction with that actually observed in the sample.

\subsection{Domestic Client-Networks and High Reserve Value}

I shall now bolster the hypothesis that the seven dealers have a high reservation value for frequent participation by examining dealer-specific attributes that might account for high reserve value, and whether the behavior of these seven dealers is consistent with these attributes.

Since primary dealers intermediate between the issuer and end- investors, ${ }^{40}$ in addition to the compensations from the issuer via the primary dealer con-

\footnotetext{
${ }^{39}$ In general, the maximum amount that a dealer can bid for himself is based on his past primary market winning share and secondary market trading share, net of his current holdings of the auctioned security. But the Bank of Canada stipulates that no bidder in an auction can bid for more than $25 \%$ of the issue amount. Minimum bid amount obligations require a dealer to bid at least $50 \%$ of the maximum amount he can bid.

${ }^{40}$ Institutional clients like pension funds, hedge funds, retail investors, electronic communication networks are examples of end-investors.
} 
tract, dealers also receive payments from end-investors. ${ }^{41}$ With dealers and end-investors interacting in the when-issued and secondary markets, these payments take the form of a mark-up between the price paid by the dealers for the securities in the primary market and the price at which they are either pre-sold in the when-issued market or sold ex post in the secondary market. Access to a dedicated network of end-investors impacts not just the magnitude of this pay-off, but the likelihood of obtaining the mark-ups as well.

Dealers without networks earn mark-ups as well, but through channels alternative to end-investor networks. One such channel is to hold the securities won at the auction till maturity instead of trading them in the secondary market, or just "buy-and-hold" securities. ${ }^{42}$ An alternative channel for a bidder without significant client-networks would be simply to repo the securities won at the auction to cover the long position. ${ }^{43}$ The difference in the channels through which mark-ups are earned lead to testable differences in the secondary market activity of dealers with and without client-networks.

The "buy-and-hold" strategy of dealers without networks generates the first systematic difference: the ratio of a dealer's primary market winning share to his secondary market trading share, referred to as pmy-sec in this paper, will differ across the two groups. The "buy-and-hold" strategy suggests that dealers who do not have significant client-network should have a pmy-sec that is at least as high as that of dealers who have access to significant client-networks. Repo transactions to cover long positions generates a second systematic difference between dealers with and without client networks: the ratio of a dealer's repo trade to his secondary market trading, referred to as repo-sec in this paper, will differ across the two groups. Several papers have documented the high liquidity of the repo market suggesting that both dealers with and without client-networks are likely to be active in this market. ${ }^{44}$ But dealers who do not have access to significant client-networks should have a repo-sec that is at least as high as, if not greater than, that of dealers who have access to client-networks.

I shall now test if systematic differences exist in these two ratios between the seven high reserve value dealers and other dealers in my sample as outlined above. ${ }^{45}$ Section 2.3 describes the available data which includes each dealer's

\footnotetext{
${ }^{41}$ Anecdotal evidence from market participants at the Bank of Canada, Montreal Stock Exchange, CBID (an electronic marketplace for Government of Canada securities), and Canadian Pension Plan Investment Board suggests that dealers typically incur substantial fixed costs to develop investor networks, and that access to client networks is the key factor affecting a dealer's profits.

${ }^{42}$ In this instance, the issuer plays the role of the client-network.

${ }^{43}$ The "buy-and-hold" strategy would appear to be an expensive way to finance the inventory of the securities won at the auctions unless a dealer has inelastic demand for the securities. For example, a dealer may be a payments and settlement systems counter party. Since government securities form a collateral to access the payments and settlement systems, it could have an inelastic demand corresponding to its collateral requirements.

${ }^{44}$ Morrow (1995) documents the dramatic growth of the repo market in Canada.

${ }^{45}$ If dealer order book data was available, a direct test would be whether dealer markups differ depending on whether a dealer has high reservation value or not. But order book data is not available; consequently, an indirect test has been constructed.
} 
bi-weekly secondary and repo volume traded. Combining this with the primary market data, I can obtain for each dealer the ratio of his primary market share to secondary market trading share, and the ratio of his repo trade to secondary market trade.

For the regressions that follow, the sample comprises of all dealers who participated in at least one auction held in the period 1992-2003 covered by this study. ${ }^{46}$ The first regression tests if differences exist in the ratio of the primary market winning share to the secondary market trading share between the seven high reservation value dealers and other dealers. In Table 1, the dependent variable is a dealer's primary market share to his secondary market trading share, with both shares obtained from quarterly level data. ${ }^{47}$ In Column (1), this is regressed on a dummy variable and a set of control variables. The dummy variable takes the value of one for the seven high reserve value dealers and zero for the other dealers. The control variables account for factors other than bidder-specific attributes that could affect the primary market winning share and secondary market trading share for all dealers. As an example, during the course of my sample, the issue amount first increases and then decreases steadily corresponding to different macroeconomic environment in the Canadian economy. Fleming (2002) shows that smaller issue amounts lead to less liquid secondary market. Consequently, dealers may cut back on the secondary market trading much more than the decline in their primary market winnings. Additionally, my sample spans a fairly long period that has seen the secondary market developing in Canada leading to smaller transaction costs. ${ }^{48}$ With declining transaction costs in secondary market, dealers are likely to trade more so that the secondary market trading share to primary market share could be high on account of this effect. To attribute the variation in pmy-sec to differences in bidder's reservation values, I need to control for these effects. Since I do not have data either on liquidity premia or transactions costs in these markets, I use a quarterly fixed-effect specification to control for these effects. This amounts to looking at how the primary market share to secondary market share varied across high and low reserve value dealers within a quarter. ${ }^{49}$ The first column in Table 1 shows that indeed there is a statistically significant difference between the seven high reserve value dealers and the other dealers. Dealers other than

\footnotetext{
${ }^{46}$ These dealer could be primary dealers or other government securities distributors. Customers are not included as they are not required to report trading data to the Investors Dealers Association. Additionally, if either of the primary market trades, secondary market trades or repo trades are zero for a dealer, that observation is dropped from the data.

${ }^{47}$ Shares were aggregated at the quarterly level for two reasons. First, bonds of a specific duration are auctioned only once during a quarter even though treasury bills are auctioned on a bi-weekly basis. Second, auction dates do not match the bi-weekly dates when dealers submit audited reports of the volume traded in the secondary market.

${ }^{48}$ See Anderson and Lavoie (2004).

${ }^{49}$ The assumption underlying the quarterly fixed-effect specification is that the factors affecting the primary and secondary markets are relatively unchanged during the quarter of a year. The quarterly fixed-effect serves to capture these relatively invariant but unobserved developments in the primary and secondary markets, that affect the ratio of the primary to secondary market share of all bidders within a quarter.
} 
the seven high reserve value dealers trade only 40 cents of every dollar of the security won at an auction. In contrast, for every dollar of the security won at the auction, the seven high reserve value dealers trade 1.43 dollars! Thus, similarly to dealers with significant client-networks, the seven high reserve value dealers appear to trade the securities won at the auction much more than the other dealers.

I now turn to the second aspect of a dealer's resale strategy, the ratio of his bi-weekly repo volume traded to his secondary market trading volume, both measured in Canadian dollars. This is the dependent variable in the regressions in Table 2. It is regressed on a dummy variable and control variables. The dummy variable is one in case the dealer is a high reserve value dealer, and is zero otherwise. The control variables need to account for the development of the secondary and repo markets in Canada which were the result of a complex set of regulatory and structural changes. ${ }^{50}$ Since I do not have data that might capture these developments, ${ }^{51} \mathrm{I}$ account for them econometrically by estimating a quarterly fixed-effect regression specification. The quarterly fixed-effect captures the unobserved component of the repo to the secondary market traded volume common to all dealers within a quarter, presumably due to the regulatory and structural changes that influenced the developments of the repo and secondary markets in Canada. The results of this regression are reported in Column (2) of Table 2. I find statistically significant difference between the high reserve value dealers and other dealers. ${ }^{52}$ While the seven high reserve value dealers repo 4 dollars worth of the security for each dollar of the security traded, other dealers repo 6 dollars worth of the security for each dollar of the security traded. ${ }^{53}$

Additional support for the hypothesis that the difference in the selling strategies of the seven high reserve value dealers and other dealers are similar to dealers with and without significant client-networks, respectively is provided by a test that looks at how the difference in selling strategies between the two groups varies across bonds and treasury bills. Since bonds have a relatively longer maturity than treasury bills, many more factors enter into forming expectations about prices of bonds than bills. Hence, one might expect that the value of significant client-networks would be much more for bonds than bills, and as a result the differences in the selling strategies between the seven high reserve value dealers and other dealers would be much more pronounced for

\footnotetext{
${ }^{50}$ See Morrow (1994-95) for an extensive discussion of the repo market in Canada. The rapid growth of the repo market was the result of regulatory changes (as an example, tax treatment of repos and securities loans)and structural changes (as an example, entry of the US dealers in early 1990s who were used to financing their inventory of securities through repos, and the introduction of broker screens in the 1990s providing traders with price quotes).

${ }^{51}$ I do not have data to back-out a measure of transaction costs in these markets, especially how these transaction costs may have changed differently between the secondary and the repo markets due to the changes in the regulatory environment and other structural changes. I could document all the possible regulations and structural changes.

${ }^{52}$ Since the repo market is primarily an overnight market, note that the repo trades are almost 5 times the secondary market trades irrespective of the type of dealer and asset.

${ }^{53}$ The difference is significant at $95 \%$.
} 
bonds than bills. The results below show that this is the case. This is also consistent with the differences in the primary market behavior of participants in bond and treasury bill auctions noted by Hortaçsu and Sareen (2004). ${ }^{54}$

In Table 2, Columns (2) and (3), I re-run the regression in Column (1), but now separately for treasury bills and bonds, respectively. First note that reflecting the greater uncertainty in pricing of bonds compared with treasury bills, I find that corresponding to each dollar of the security allotted at an auction, an additional 33 cents of treasury bills would be traded compared with bonds. Next, reflecting this uncertainty in the pricing of bonds, I find that for each dollar of the security won at the auction, the difference in bond trading between high and low reserve value dealers is nearly twice the difference in the treasury bill trading between the two groups. ${ }^{55}$

The same exercise is repeated with the ratio of a dealer's repo volume traded to secondary market trading volume. In Table 2, Columns (2) and (3), I rerun the regression in Column (1), but now separately for treasury bills and bonds, respectively. Though I do find there is a statistically significant difference between treasury bills and bonds, the difference in the repo-sec between high and low reserve value dealers is more pronounced for bills rather than bonds. ${ }^{56}$ But the repo contract, which is most commonly an overnight contract, has the shortest maturity compared with either bills and bonds, and consequently the least pricing uncertainty. It is likely that this makes the bond-bill distinction of second order compared with whether the transaction is a security trade or a repo of the underlying security, ${ }^{57}$ effects that I have been unable to disentangle.

The significant differences in the selling strategies of the seven high reserve value dealers and other dealers, and that these are similar to differences between dealers with and without significant client networks, suggests that access

\footnotetext{
${ }^{54}$ Hortaçsu and Sareen (2005) show that bidding decisions of dealers are more responsive to arrival of customer order flow information in bond auctions compared with treasury bill auctions. Similarly, the best response of customers to a dealer's use of his order flow information is more pronounced for bond auctions than treasury bill auctions.

${ }^{55}$ For bonds, while the seven high reserve value dealers match a dollar and twenty five cents in trade for each dollar won at the auction, the other dealers trade only 27 cents for each dollar won. The difference is significant at $99 \%$. For treasury bills, while the seven high reserve value dealers match $\$ 2.00$ for each dollar won at the auction, the other dealers trade 50 cents for each dollar won and the difference is significant at $90 \%$. The difference between treasury bills and bonds was also found to be statistically significant at $90 \%$. To test this hypothesis (that the coefficient on the dummy variable "High Value Dealer" is statistically significant between bonds and bills) the regression in Column (1), Table 1 was re-run adding a dummy variable "Bond" and it's interaction with the dummy variable "High Value Dealer".

${ }^{56}$ For each dollar of the security traded in the secondary market, the difference in treasury bill repos between high and low reserve value dealers is nearly six times the difference in the bond repos between the two groups, and this difference is significant at $99 \%$.

${ }^{57}$ I find evidence consistent with this: the ratio of a dealer's repo volume traded to secondary market trading volume does not differ between bonds and bills. Repo-sec was regressed on a dummy variable that had a value of 1 if the security was a bond and zero otherwise. A dealer and quarter fixed effect specification was used which amounts to looking at the bond-bill difference in the repo-sec for a dealer within a quarter. I find that for each dollar of secondary trading, a dealer repos an additional 26 cents of bonds than bills but this difference is not statistically significant.
} 
to client-networks may well account for a dealer's high reservation value for frequent participation.

\section{Dealers Respond to Changes in Obligations- Advantages of the Primary Dealer Contract}

The results in the previous section suggest that the participation choice of high reservation value dealers is relatively invariant to the terms of the primary dealer contract. But between them, there is a high likelihood of under subscribed primary issuance. Consequently, the effectiveness of the primary dealer contract as a channel to guarantee a fully subscribed issuance hinges on a dealer's decision, whether to participate as a primary dealer or a non-primary dealer, responding to a change in the underlying advantages-obligations. The analysis in this section suggests that dealers other than the seven high reserve value dealers respond to obligations-advantages offered by the primary dealer contract.

Let $D_{p d}^{i j}$ be a binary variable that represents the event that a bidder $i$ participates as a primary dealer or not in an auction $j$, with

$$
\begin{aligned}
D_{p d}^{i j} & =1 \quad \text { if } \quad \pi_{p d}^{i j} \geq 0 \\
& =0 \text { if } \quad \pi_{p d}^{i j}<0 .
\end{aligned}
$$

$\pi_{p d}^{i j}$ is primary dealer $i$ 's profit function in auction $j$. It has two components one of which is attributable to the issuer and the other to end-investors. Profits for intermediation that derive from the issuer comprise of awarded advantages net of the cost of complying with participation obligations. Compensations from end-investors comprise the mark-up between the price at which securities are purchased at the primary issuance and the price at which they are sold in the spot or forward markets. I shall assume that the two components are additively separable in the econometrics model estimated below. ${ }^{58}$ A dealer will participate as a primary dealer if this bidder's profits from participating as a

\footnotetext{
${ }^{58}$ The two components of profit are not additively separable. Suppressing the auction level superscript and the expectations operator, the profit function of a representative primary dealer is his advantage-adjusted payoff from frequent participation;

$$
\begin{aligned}
\pi_{p d}^{i} & =\left[\pi_{\text {freq }}^{i} \mid \text { advantages }\right] \\
& =\left[r_{\text {freq }}^{i}-P_{\text {freq }}^{*} \mid \text { advantages }\right]
\end{aligned}
$$

where $\pi_{\text {freq }}^{i}$ are profits from frequent participation defined as the difference in a dealer's reservation value for frequent participation $\left(r_{\text {freq }}^{i}\right)$ and the price at which the seller is offering it $\left(P_{\text {freq }}^{*}\right)$. A dealer's reserve value for frequent participation derives from the mark-up between the price paid $\left(P_{\text {paid }}\right)$ which is the cutoff price at an auction, and the price at which he expects to trade the security in the spot or forward markets $\left(P_{\text {resale }}^{i}\right)$. Thus,

$$
r_{\text {freq }}^{i}=\left[\left(P_{\text {paid }}-P_{\text {resale }}^{i}\right) X_{\text {wins }}^{i}\right] \wp_{\text {win }}^{i} \wp_{\text {resale }}^{i} .
$$

$X_{w i n s}^{i}$ is dealer $i$ 's expectation of the number of units of the security he will win. $\wp_{w i n}^{i}$ and $\wp_{\text {resale }}^{i}$ is the probability that dealer $i$ will win and be able to resell the securities, respectively.
} 
primary dealer are nonnegative. In this instance the variable $D_{p d}^{i j}$ will take the value $1 . D_{p d}^{i j}$ will take the value 0 in case a bidder's profits from participating as a primary dealer are negative. ${ }^{59}$

For each auction in my sample, I observe each bidder's ex post participation choice: whether this bidder chooses to participate as a primary dealer or not. Hence, I actually observe the variable $D_{p d}^{i j}$ for each bidder. While all dealers who were present in at least one auction as primary dealers during the sample period are included, ${ }^{60}$ the focus is on dealers other than the seven high reserve value dealers who would potentially self-select themselves into primary dealership vs non-primary dealership depending on the incentives underlying the two contracts. $^{61}$

Since I observe the binary variable $D_{p d}^{i j}$, a logit regression is used to model the probability of a dealer participating as a primary dealer in an auction. The two sets of variables that affect this choice are compensations from the issuer via the incentives created by the advantages-obligations of the primary dealer contract, and the compensations from the end-investors. Indeed, the analysis below shows that the participation choice of dealers other than the seven high reserve value dealers is sensitive to the incentives of the primary dealer contract after controlling for compensations from end-investors.

Compensations from end-investors are not directly observable as dealer order book data is not available. Consequently I use three auction and bidder level variables as a proxy for compensations from end-investors: ${ }^{62}$ a dealer's primary

\footnotetext{
${ }^{59}$ In this instance he could either chose to exit the primary market or continue to be present but as a non-primary dealer, viz, a government securities distributor or customer. In this paper, the two alternatives are treated symmetrically in that $D_{p d}^{i j}=0$ in either case as data that could distinctly identify the two affects is not available.

${ }^{60}$ Bidders includes both dealers and customers. While customers have always bid in the auctions through dealers, I observe their bidding only after October 1998. Additionally, customers are neither subject to obligations nor awarded advantages. Since the aim of this paper is to examine the change in participation decisions in response to the incentives of the primary dealer contract, customers are included only to the extent a primary dealers switches to bidding as a customer after October 1998. There are no instances during the sample period of customers switching to primary dealers.

${ }^{61} \mathrm{~A}$ dealer's profits from participating as a primary dealer being non-positive does not necessarily imply that his profits from participating as a non-primary dealer are non-positive as well. For example, in a era where the advantages offered to a bidder under the primary dealer contract are negligible, bidding as a customer might be relatively more profitable than bidding as a primary dealer as customers are not subject to any of the obligations, and hence participation costs, under the primary dealer contract. I actually observe two bidders who switch from participating as primary dealers to customers in the post 1998 period.

${ }^{62}$ All three variables are quantity-based rather than price-based variables. The commoditization of government securities that drives the difference between the when-issued price and the cutoff yield to be statistically insignificant, suggests that the spreads that dealers makes from investors is at competitive levels. This argument is supported by both market participants and academic studies (see Rocholl, 2005 who documents that dealers do not make money in German Bund auctions). Consequently, it seems reasonable to assume that it is the difference in quantity-based variables across dealers, like the magnitude of order flow, that account for the difference in compensations from end-investors rather than dealer-specific price-based variables, like mark-ups.
} 
market share in an auction, and his secondary market trading share and repo market share in the period corresponding to the auction. ${ }^{63}$

Compensations from the issuer while easily interpretable as the difference between the participation obligations imposed on and advantages awarded by the Bank of Canada, are not directly observed. But I do observe a policy experiment in October 1998 by the Bank of Canada where it reduced compensations for intermediation, de facto increasing the price of primary dealership. A dummy variable "October1998" is used to capture this policy experiment. It takes the value 1 if the auction is held after the policy change, and take a value of 0 otherwise. This dummy variable on its own does not capture the policy experiment: indeed I observe, corresponding to Figure 4, that participation probability increases by $4 \%$ following the policy experiment. ${ }^{64}$ This follows from the policy experiment impacting dealers differently: not all dealers who bid as primary dealers following the policy experiment, continued to do so through the rest of the sample, and we need to control for this dealer-level effect. ${ }^{65}$ This is done by including a dummy variable "newpd". The dummy variable is one if a dealer's first-time participation as a primary dealer is after the policy experiment, and zero if it is before the policy experiment. ${ }^{66} \mathrm{I}$ shall refer to these dealers as "new" and "old" respectively. The inclusion of the "newpd" dummy amounts to looking at the variation in participation probability for the new primary dealers and old primary dealers as a group. The "newpd" dummy is also interacted with the October1998 indicator to assess how participation between old and new primary dealers varies in response to the decline in compensations underling the policy experiment. The logit regression specification used is:

$$
\begin{aligned}
\operatorname{Pr}\left(D_{p d}^{i j}=1\right)= & F\left(\text { PrimaryMarketShare }_{i j}+\text { SecondaryMarketShare }_{i j}\right. \\
& + \text { RepoShare }_{i j}+{\text { October } 1998_{j}} \\
& + \text { NewPD }_{i}+(\text { NewPD } \\
& \left.+\epsilon_{i j}\right) *
\end{aligned}
$$

where $F$ is the logistic cumulative distribution function.

\footnotetext{
${ }^{63}$ Secondary market trades and repo transactions are reported bi-weekly and the dates do not necessarily coincide with the dates on which auctions are held. Consequently, a dealer's secondary market trading share corresponds to his share in secondary market trading reports that are recorded immediately succeeding an auction.

${ }^{64}$ The regression is:

$$
\operatorname{Pr}\left(D_{p d}^{i j}=1\right)=F\left(\text { PrimaryMarketShare }_{i j}+\text { SecondaryMarketShare }_{i j}\right.
$$$$
\left.+ \text { RepoShare }_{i j}+\text { October } 1998_{j}+\epsilon_{i j}\right),
$$

where $F$ is the logistic cumulative distribution function.

${ }^{65} \mathrm{An}$ indicator variable for high reserve value dealers will not be an effective control as these dealers continue bidding as primary dealers following the policy change

${ }^{66}$ Whether the dealer continues to bid as a primary dealer or not is immaterial to the definition of "newpd". For example, a dealer who first bids as a primary dealer in 1995 but as a government securities distributor from 1997 onwards, is assigned a value of zero. A dealer who bids throughout the sample as a primary dealer, viz, the high reserve value dealers, is also assigned a value of zero. However, the high reserve value dealers do not add any significance to the regression as $D_{p d}^{i j}=1$ for all observations in the sample.
} 
While dealer-level affects are not visible in Figure 4, an effect that is visible is the possibility of an under subscribed auction and consequently the impact of the policy experiment, being much more pronounced for bonds than treasury bills. Hence, I need to control for bond-bill differences as well. This is done by running the logit regression specified above for the whole sample, and separately for bonds and treasury bills.

Table 3 reports the results of the logit regression. The three variables that proxy for compensations from end-investors - primary market winning share, secondary market trading share, and repo share - have a positive and statistically significant impact on the likelihood of a dealer bidding as a primary dealer. ${ }^{67}$ The relative importance of the three varies depending on whether the auction is a treasury bill or bond auction. The likelihood of bidding as a primary dealer is most greatly affected by a dealer's repo share in bond auctions and primary market share in treasury bill auction. ${ }^{68}$ This suggests that the option to repo is much more valuable to a dealer for bonds compared with bill, and is consistent with bonds being subject to greater price uncertainty compared with treasury bills noted by Hortaçsu and Sareen (2005).

Compensations from the issuer via the primary dealer contract have a positive and statistically significant impact on a dealer's participation decision as well. The higher price of primary dealership underlying the policy experiment in October 1998 affects both new primary dealers and old primary dealers. The likelihood of an old primary dealer participating as a primary dealer decreased by $10 \%$ following the policy experiment. ${ }^{69}$ The new primary dealers bid only in $37 \%$ of the auctions following the policy experiment as primary dealers. While most of these dealers exit the market, some of them bid either as customers or government securities distributors in the remaining auctions. Finally, both these effects are much more pronounced for bonds compared with bills.

Thus, this section provides convincing evidence that a dealer's decision whether to participate as a primary dealer or a non-primary dealer responds to a change in the obligations-advantages underlying the primary dealer contract.

\section{Conclusion}

Using a unique data set from the Government of Canada securities auctions this paper concludes that imposing participation obligations on primary dealers guarantees a fully subscribed issuance, but that complying with primary dealer

\footnotetext{
${ }^{67} \mathrm{~A} 1 \%$ increase in the primary market share, secondary market share, and repo share increases the likelihood of bidding as a primary dealer by $1 \%, 0.3 \%$ and $0.1 \%$, respectively.

${ }^{68} \mathrm{~A} 1 \%$ increase in a dealer's repo (primary market) share increases the likelihood of this dealer bidding as a primary dealer by $0.2 \%(3 \%)$ in bond (treasury bill) auctions.

${ }^{69}$ The coefficient on the dummy variable "Oct 1998" measures the post-pre policy experiment difference in participation probability of old primary dealers, viz, dealers whose first-time bid as a primary dealer was prior to the policy experiment.
} 
obligations involves participation costs necessitating compensations from the issuer.

From the analysis in this paper, one can begin to understand why what might appear as a relatively costly issuance method revolving around human intermediaries is a popular method to sell government debt around the world. The role of primary dealers in preventing auction fails is likely to become center-stage in government debt issuance as the credit crisis leads to the demise of several banks who bid as primary dealers in many countries (as an example, Lehman Brothers, Bear Stearns), along with an unprecedented amount of government bonds to sell to finance measures to reverse a 1930s style recession.

While the paper conclusively establishes that intermediation in the primary market for treasuries involves participation costs, a related question is how this impacts the conventional revenue ranking of the discriminatory and uniform price auctions, as well as, whether participation costs are of first-order importance relative to the pricing rule. This will be explored in future work. 


\section{References}

Adams, William J., and Janet L. Yellen, 1976, Commodity bundling and the burden of monopoly, Quarterly Journal of Economics 90, 475498.

Anderson, Stacey, and Stphane Lavoie, Summer 2004, The Evolution of Liquidity in the Market for Government of Canada Bonds, Bank of Canada Review, 19-31.

Arnone, Marco and George Iden, 2003, Primary Dealers in Government Securities: Policy Issues and Selected Countries' Experience, IMF working paper WP/03/45.

Ausbel, Larry M., and Peter Cramton, 1998, Demand reduction and inefficiency in multi-unit auctions, working paper, University of Maryland.

Back, Kerry, and Jamie F. Zender, 1993, Auctions of divisible goods: on the rationale for the treasury experiment, Review of Financial Studies 6(4):733764 .

Barclay, Michael, Terrence Hendershott, and D. Timothy McCormick, 2003, Competition among trading venues: Information and trading on electronic communications networks, Journal of Finance 58, 2637-2666.

Barclay, Michael, Terrence Hendershott, and Kenneth Kotz, 2006, Automation versus intermediation: evidence from treasuries going off the run, Journal of Finance 61, 2395-2414.

Bikhchandani, Sushil, and Chi-fu Huang, 1989, auctions with resale markets: an exploratory model of treasury bill markets. Review of Financial Studies 2,311340 .

Bikhchandani, Sushil, and Chi-fu Huang, 1993, the economics of treasury security market, Journal of Economic Perspectives 7, 117-134.

Biasis, Bruno, Larry Glosten, and Chester Spatt, 2005, Market microstructure: a survey of microfoundations, empirical results, and policy implications, Journal of Business 8, 217-264.

Das, Sanjiv R., and Rangarajan K. Sundaram, 1997, auction theory: a summary with applications to treasury markets, NBER Working paper \# 5873 .

Demsetz, Harold, 1968, The cost of transacting, Quarterly Journal of Economics 82, 33-53.

Engelbrecht-Wiggans, Richard, and Charles Kahn, 1998, Multi-unit pay-yourbid auctions with variable award, Games and Economic Behavior 23, 2542 . 
Fleming, Michael J., 2002, Are larger treasury issues more liquid? evidence from bill reopenings, Journal of Money, Credit and Banking 34(3), 709735 .

Grossman, Sanford, 1992, The informational role of upstairs and downstairs markets, Journal of Business 65, 509-529.

Hortaçsu, Ali, 2002, Mechanism choice and strategic bidding in divisible good auctions: an empirical analysis of the Turkish treasury auction market, working paper, University of Chicago.

Hortaçsu, Ali, and Samita Sareen, 2005, Order flow and the formation of dealer bids: information flows and strategic bidding in the Government of Canada Securities Auctions. NBER WP \# 11116.

Ho, Tracey, and Hans R. Stoll, 1981, optimal dealer pricing under transactions and return uncertainty, Journal of Financial Economics 9, 47-73.

Kastl, Jakub, 2006, Discrete bids and empirical inference in divisible good auctions, working paper, Stanford.

Levin, John, and James L. Smith, 1994, Equilibrium in auctions with entry, American Economic Review 84(3), 585-599.

Lyons, Richard, 2001, The Microstructure Approach to Exchange Rates, MIT.

Madhavan, Ananth, and George Sofianos, 1998, An empirical analysis of NYSE specialist trading, Journal of Financial Economics 48, 189-210.

Malvey, Paul F., and Christine M. Archibald, 1998, Uniform price auctions: update of the treasury experience, technical Report, Department of the US Treasury.

Mas-Colell, A., Michael D. Whinston, J.R. Green, 1995, Microeconomic Theory, Oxford University Press, New York.

McAfee, Preston R., and John McMillan, 1987, Auctions with a stochastic number of bidders, Journal of Economic Theory 43(1), 1-19.

Morrow, Ron, Winter 1994-95, Repo, reverse repo and securities lending markets in Canada, Bank of Canada Review, 61-70.

Noussair, Charles, 1995, Equilibria in a multi-object uniform price sealed bid auction with multi-unit demands, Economic Theory 5, 337-351.

Nyborg, Kjell G., and Suresh M. Sundaresan, Discriminatory versus uniform treasury auctions: evidence from when-issued transactions, Journal of Financial Economics 42, 63-105. 
Nyborg, Kjell G. and Ilya Strebulaev, 2004, Multiple unit auctions and short squeezes, Review of Financial Studies 17, 849-877.

O'Hara, Maureen, 1995, Market Microstructure Theory, Blackwell.

Rocholl, Jrg, February 2005, Discriminatory Auctions with Seller Discretion: Evidence from German Treasury Auctions, working paper, UNC KenanFlagler business school.

Sareen, Samita, Cross-Country Comparison of Models for Issuance of Government Securities, 2004. Working paper, Duke University.

Seppi, Duane, 1990, Equilibrium block trading and symmetric information, Journal of Finance 45, 73-94.

Stoll, Hans R., 1978, The supply of dealer services in securities markets, Journal of Finance 33, 1133-1151.

Umlauf, Steven, 1993, An empirical study of the Mexican treasury bill auctions, Journal of Financial Economics 33, 313-340.

Varian, Hal, 1990, Intermediate microeconomics: a modern approach, W.W. Norton. 


\section{Figure 1: Government Securities Market}

Primary Market

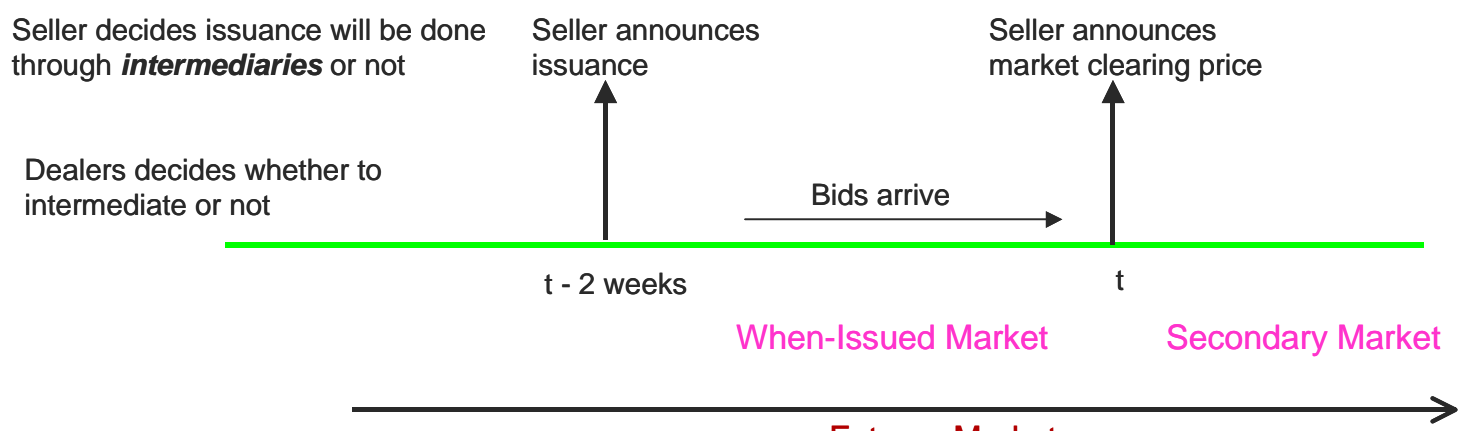

Futures Market 
Figure 2: Distribution of Buyers in Reserve Value Space for Frequent Participation

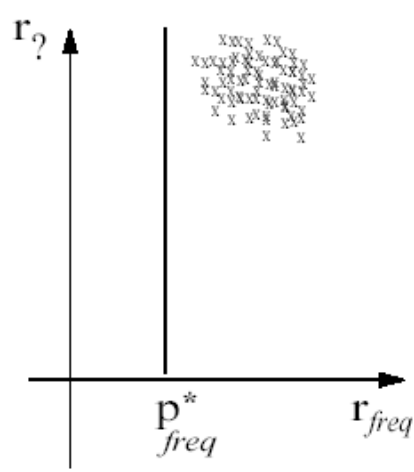

(a)

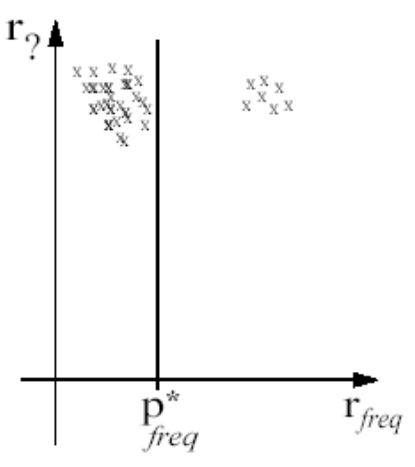

(b)

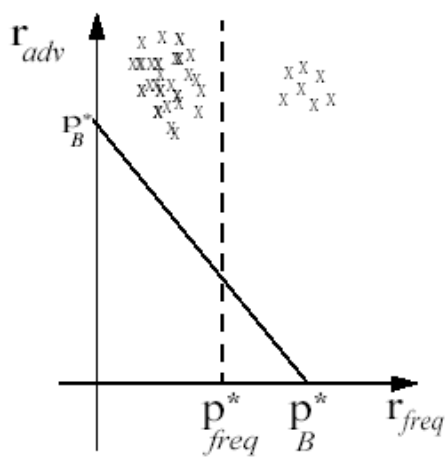

(c) 
Figure 3: Auction Cover Ratio within 5 Basis Points of Cutoff Yield

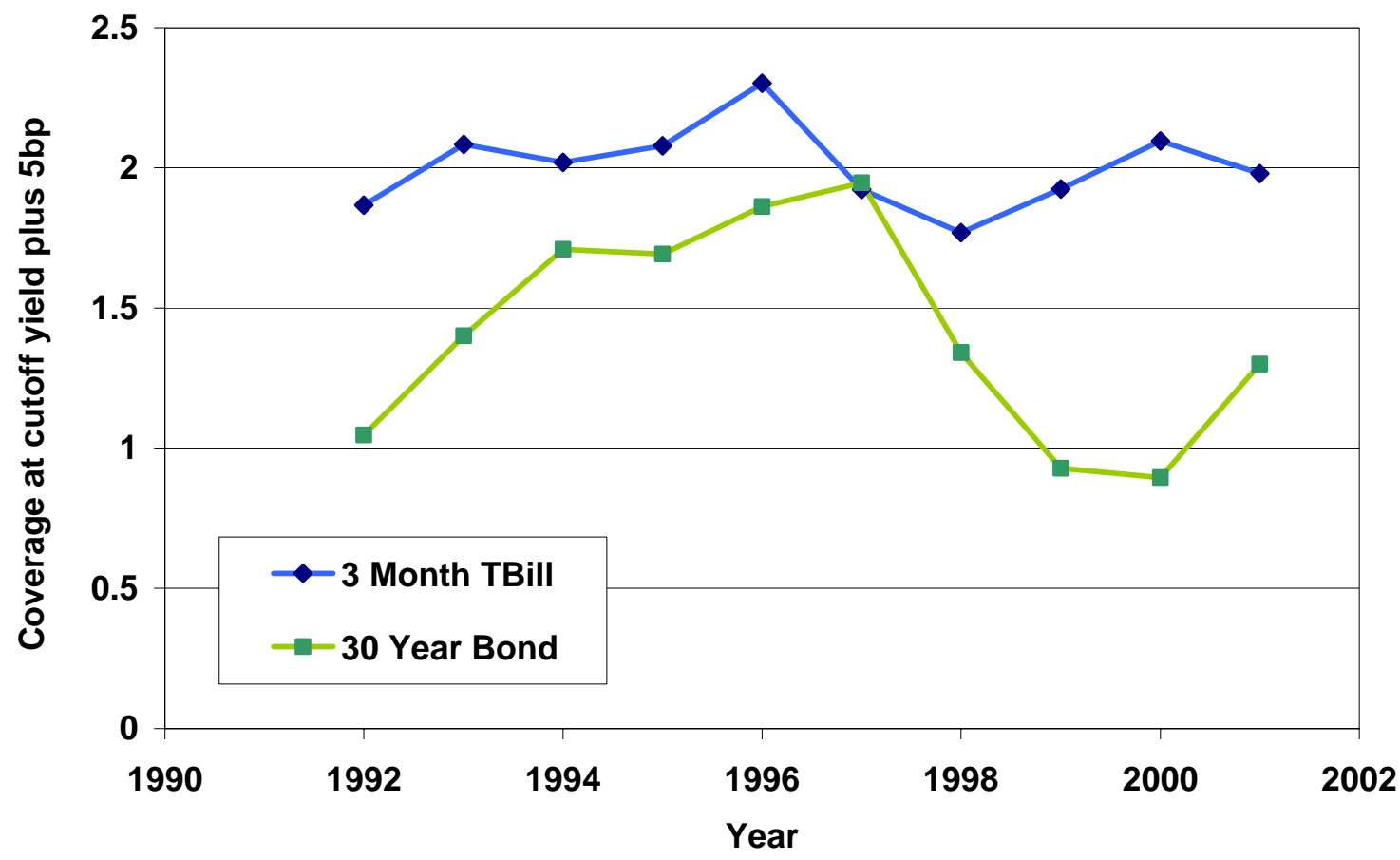


Figure 4: Primary Dealers in Canada (Quarterly Total)

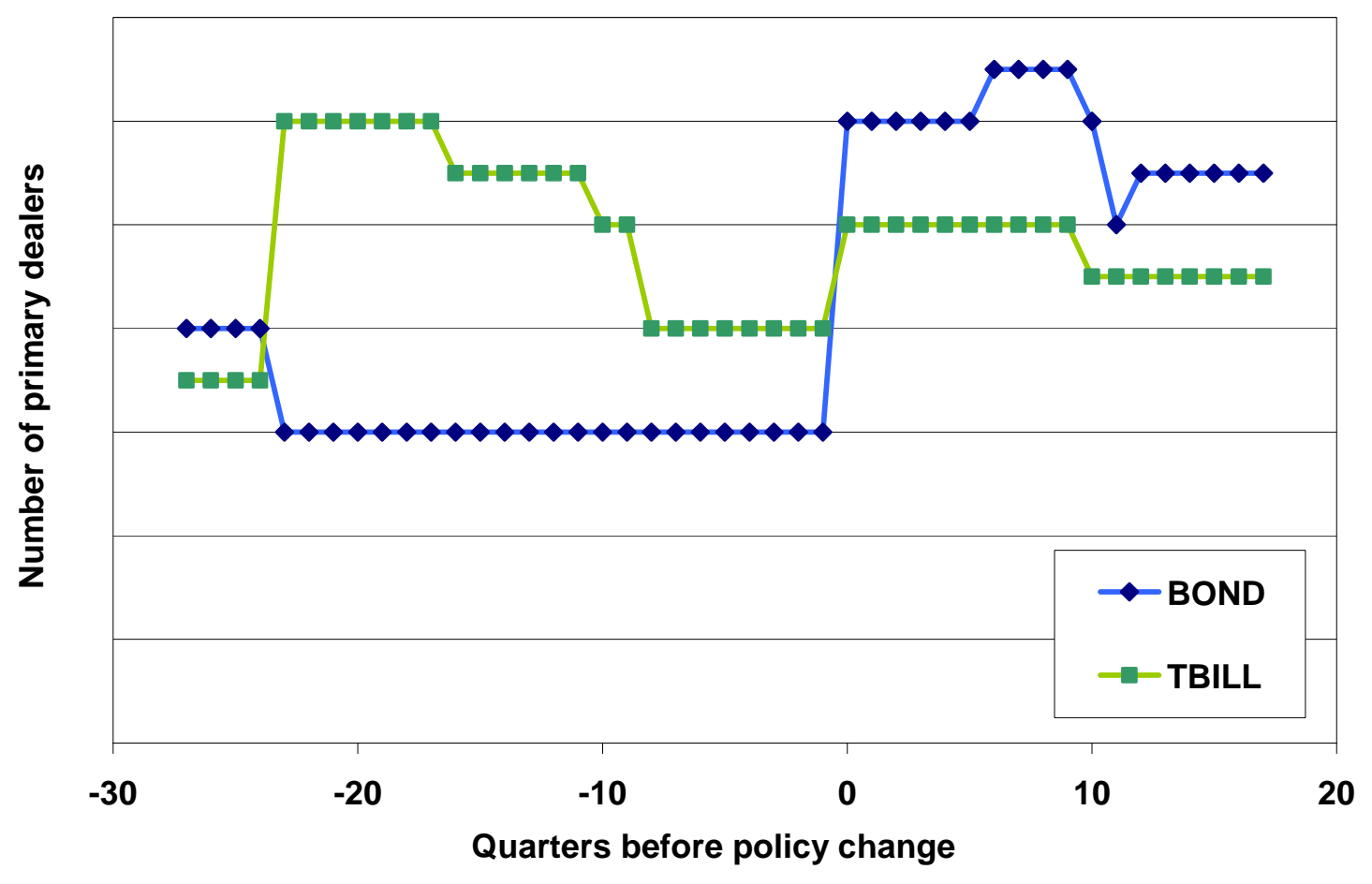




\section{Table 1: Difference in Primary to Secondary Market Share of High Reserve Value Dealers and other Dealers}

Column (1) reports the estimated coefficients from a regression in which the dependent variable is the ratio of a dealer's primary market winning share (in percent) to his secondary market trading share (in percent); Column (2) and Column (3) report results from the same regression but only for the treasury bill market and bond market, respectively. All shares are obtained from quarterly level data. The independent variable is an indicator variable for the seven high reserve value dealers. The effect of the changing transaction costs in the primary and secondary market for GoC securities is purged by estimating a quarterly fixed effects specification; thus the estimates reflect within-quarter variation between high reserve value dealers and other dealers. Standard errors are reported below the coefficients. Significance at 10-percent, 5-percent and 1-percent levels are denoted by $(*),(* *)$, and $(* * *)$.

\begin{tabular}{|c|c|c|c|}
\hline & $\begin{array}{c}\text { Primary Market } \\
\text { Winning Share to } \\
\text { Secondary Market } \\
\text { Trading Share }\end{array}$ & $\begin{array}{c}\text { Primary Market } \\
\text { Winning Share to } \\
\text { Secondary Market } \\
\text { Trading Share }\end{array}$ & $\begin{array}{c}\text { Primary Market } \\
\text { Winning Share to } \\
\text { Secondary Market } \\
\text { Trading Share }\end{array}$ \\
\hline & $(1)$ & $(2)$ & (3) \\
\hline & Entire Sample & Treasury Bills & Bonds \\
\hline High Value Dealer & $\begin{array}{l}-2.03 \\
(0.721)^{* * *}\end{array}$ & $\begin{array}{c}-1.47 \\
(1.006)^{*}\end{array}$ & $\begin{array}{c}-2.7 \\
(1.032)^{* * *}\end{array}$ \\
\hline Constant & $\begin{array}{l}2.73 \\
(0.314)^{* * *}\end{array}$ & $\begin{array}{c}1.92 \\
(0.424)^{* * *}\end{array}$ & $\begin{array}{c}3.64 \\
(0.463)^{* * *}\end{array}$ \\
\hline Quarterly Fixed Effect & $\mathrm{Y}$ & $\mathrm{Y}$ & $\mathrm{Y}$ \\
\hline Observations & 868 & 452 & 416 \\
\hline No. of Quarters & 13 & 13 & 13 \\
\hline R-sq overall & 0.008 & 0.003 & 0.017 \\
\hline R-sq within quarter & 0.009 & 0.005 & 0.018 \\
\hline
\end{tabular}




\section{Table 2: Difference in the Repo to the Secondary Market Trade of High Reserve Value Dealers and other Dealers}

Column (1) reports the estimated coefficients from a regression in which the dependent variable is the ratio of a dealer's bi-weekly repo volume traded to secondary market volume traded both in Canadian dollars; Column (2) and Column (3) report results from the same regression but only for the treasury bill market and bond market, respectively. The independent variable is an indicator variable for the seven high reserve value dealers. The effect of the regulatory and structural changes that impacted the development of the secondary and repo markets is purged by estimating a quarterly fixed effects specification; thus the estimates reflect within-quarter variation between high reserve value dealers and other dealers. Standard errors are reported below the coefficients. Significance at 10-percent, 5-percent and 1-percent levels are denoted by $(*),\left({ }^{* *}\right)$, and $(* * *)$.

\begin{tabular}{lccc}
\hline \hline & $\begin{array}{c}\text { Repo Volume Traded } \\
\text { to Secondary Market } \\
\text { Traded Volume }\end{array}$ & $\begin{array}{c}\text { Repo Volume Traded } \\
\text { to Secondary Market } \\
\text { Traded Volume }\end{array}$ & $\begin{array}{c}\text { Repo Volume Traded } \\
\text { to Secondary Market } \\
\text { Traded Volume }\end{array}$ \\
\hline \hline & Entire Sample & Treasury Bills & Bonds \\
High Value Dealer & & & \\
& -2.64 & -6.11 & -0.40 \\
& $(1.163)^{* *}$ & $(2.72)^{* *}$ & $(0.223)^{* *}$ \\
Constant & & & \\
& 6.29 & 8.01 & 5.49 \\
& $(0.825)^{* * *}$ & $(2.011)^{* * *}$ & $(0.152)^{* * *}$ \\
Quarterly Fixed Effect & & & \\
\hline $\begin{array}{l}\text { Observations } \\
\text { No. of Quarters }\end{array}$ & 10627 & $\mathrm{Y}$ & 5876 \\
R-sq overall & 35 & 4751 & 35 \\
R-sq within quarter & 0.0001 & 35 & 0.0001 \\
& 0.0005 & 0.0002 & 0.0005
\end{tabular}




\section{Table 3: Dealers Respond to Changes in the Obligations-Advantages of the Primary Dealer Contract}

Each column reports the estimated marginal coefficients from a logit regression in which the dependent variable is a dummy variable that takes the value 1 if the bidder participates as a primary dealer in an auction, and is zero otherwise. The first three independent variables are specific to a dealer within an auction: primary winning share is a dealer's share of allotted bids to the total allotted bids in an auction; secondary trading share and repo share is a dealer's share of secondary market trading and repo transactions, respectively, reported immediately following the auction. The fourth independent variable is an indicator variable for October 1998 corresponding to the policy experiment of the . Finally, the independent variable, New Primary Dealer, is an indicator variable that is 1 if a dealer participates as a primary dealer only after October 1998, and is zero otherwise. Standard errors are reported below the coefficients. Significance at 10 -percent, 5-percent and 1-percent levels are denoted by $(*),(* *)$, and $\left({ }^{* * *}\right)$.

\begin{tabular}{lccc}
\hline \hline & Whole Sample & Bonds & Treasury Bills \\
\hline \hline & $(1)$ & $(2)$ & $(3)$ \\
Primary Winnings Share & 0.01 & 0.00005 & 0.03 \\
& $(0.0006)^{* * *}$ & $(0.00003)^{*}$ & $(0.002)^{* * *}$ \\
Secondary Trading Share & 0.003 & 0.0005 & 0.004 \\
& $(0.0001)^{* * *}$ & $(0.00007)^{* * *}$ & $(0.0002)^{* * *}$ \\
Repo Share & 0.001 & 0.002 & 0.002 \\
& $(0.0001)^{* * *}$ & $(0.0002)^{* * *}$ & $(0.0001)^{* * *}$ \\
Oct 1998 & -0.11 & -0.09 & -0.20 \\
& $(0.01)^{* * *}$ & $(0.03)^{* * *}$ & $(0.02)^{* * *}$ \\
New Primary Dealer & -0.33 & -0.51 & -0.27 \\
& $(0.12)$ & $(0.02)$ & $(0.02)$ \\
New Primary Dealer $*$ & & & \\
Oct 1998 & 0.37 & 0.50 & 0.31 \\
& $(0.07)^{* * *}$ & $(0.02)^{* * *}$ & $(0.03)^{* * *}$ \\
\hline Observations & 27412 & 8787 & 18625 \\
Pseudo R-sq & 0.64 & 0.75 & 0.68
\end{tabular}

